\title{
Regulating Pornography: A Public Dilemma
}

by Margaret E. Thompson, Steven $H$. Chaffee, and Hayg H. Oshagan

\begin{abstract}
Contrary to expectation, respondents wbo feel more strongly that pornograpby bas negative effects, espectally on interpersomal relations between men and women, are more opposed to its regulation.
\end{abstract}

Antipornography sentiment, long associated with a conservative, moralistic U.S. political tradition, has recently arisen on the Left as well, particularly among feminist groups. Their apprehension has been fueled by what appears to be a highly profitable and growing pornography industry that explicitly mixes violence with sexual portrayals. Feminist concern has given rise to such popular movements as Take Back the Night (11) and to the introduction of model statutes defining pornography not as a criminal, legal offense but as a violation of women's civil rights.

Arguments for public controls on pornography frequently include assertions about community standards or what is "acceptable" to "society." Past surveys, however, have shown a high public tolerance for sexually oriented materials. The 1970 Report of the U.S. Commission on Obscenity and Pornography (17), for example, concluded that the industry was neither large nor controlled by organized crime, that people generally considered pornography a mixed evil with at least some socially beneficial effects, and that laws attempting to control it ought to be trimmed. In a 1985 Gallup poll for Newsweek (18), a majority of those surveyed wanted restrictions on sexually explicit materials to be no tighter than they already were, although most respondents advocated banning sexually violent materials. In legal circles the view that most pornography comes under First Amendment protections of free speech and free press has prevailed (except regarding its sale to minors, which has become a criminal offense in many places).

Margaret E. Thompson is Assistant Professor in the Department of Mass Communications, University of Denver. Steven H. Chaffee is Janet M. Peck Professor and Chairman of Communication, Stanford University. Hayg H. Oshagan is Assistant Professor in the Department of Communication, University of Michigan at Ann Arbor. The study reported here was a class project in mass communication and political behavior in the School of Journalism and Mass Communication at the University of WisconsinMadison, taught by the second author, in which the other two authors were doctoral students. The authors would like to thank the class members, particularly Tim Leutwiler and Deborah Hawley, for interviewing and other work.

Copyright (C) 1990 Journal of Communication 40(3), Summer. 0021-9916/90/\$0.0+.05 
In this article, we report findings from a small-scale public opinion survey about regulation of pornography, conducted in a community where feminist antipornographic activism has recently been at least as prominent as the more usual thunder on the Right. We assumed that this issue is inherently problematic for many people because it does not break along conventional political or demographic lines. Liberals and conservatives alike tend to value First Amendment freedoms highly. At the same time, a traditional conservative would most likely disapprove of pornography (along with other forms of open sexual activity) as an affront to conventional, "family-based" values, while the prevailing liberal view would focus more specifically on pornography's detrimental effects on relationships between men and women and on its contribution to a "culture of violence" against women. The matter is thus fraught with the conflicting pressures of freedom and regulation, creating a large difference of opinions on the topic.

\section{One important theme to consider in the debate over pornography is the question of its presumed effects. The U.S. Attorney General's Commis-} sion on Pornography, established in 1985, undertook a massive review of social scientific evidence on the effects of pornography and concluded that it has strong and deleterious effects on social behavior (16). Two members of that body dissented, however, on the grounds that such conclusions were based on the opinions of members rather than on research evidence.

Social scientists also disagree over how to interpret studies of pornography's effects. Donnerstein, whose work is frequently cited as evidence of pornography's negative social impacts, has repeatedly stressed that sexually explicit films have undesirable effects only when the sex is mixed with violence $(7,15)$. Other scholars dispute this reading of the evidence and also raise methodological questions about various effects studies (e.g., 1, 4, 5, 8, 12, 19, 20, 21, 22, 23 , 24). Fueling the debate are the different interpretations of research findings made by those who advocate various theoretical models of pornography's functions and effects (13). Given such unequivocalness among researchers, widely varying beliefs among the public about the effects of pornography, as indicated in the 1985 Newsweek poll (18), are not surprising.

In trying to discern factors that account for the wide variance of opinion on this issue, previous studies have noted considerable differences between men and women-particularly older women, who mostly favor governmental controls on pornography $(9,17)$. There is also ample evidence that consumers of pornography tend to oppose its censorship $(10,17,18)$. These, however, are scarcely surprising findings, nor do they penetrate very far into the belief structure underlying public opinions.

Most people probably have some basis for evaluating the possible effects of pornography from their personal experience. Few adult Americans have not been exposed to at least some soft-core pornography, such as sexually oriented films or magazines, and people's opinions on the desirability of pornography regulation may grow out of their personal reactions to these materials. The work of Byrne and Lambeth (3), for example, suggests that people who react 


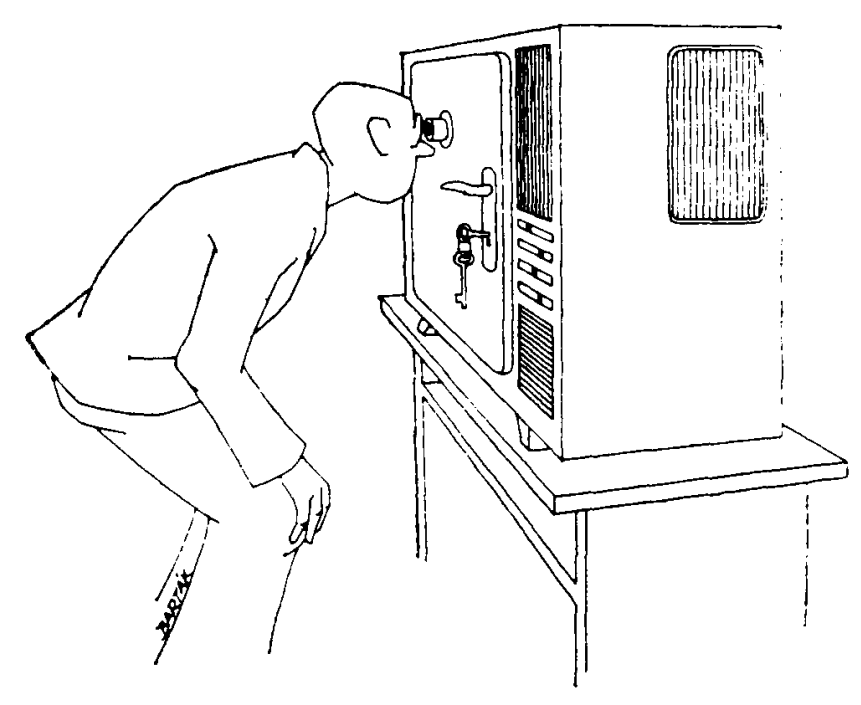

more negatively to pornographic depictions (disgust, absence of arousal, etc.) tend to favor greater restrictions on such material.

Another likely influence on opinion might be a person's general sexual attitudes, or beliefs about relationships between men and women. An adherent to traditional sexual mores, for example, might be less tolerant of the circulation of pornography. Similarly, someone who holds to traditional norms of male dominance might be less concerned about the possible role of pornography in fostering callousness toward women.

Still another influence on opinions about pornography's effects may be the extent of one's direct experience with pornographic materials-a probable indicator of favorable personal views on pornography. There is evidence that those who have greater experience with pornography tend to have more tolerant and liberal sexual attitudes, and tend not to favor restrictions on pornography $(17,18)$.

Our study is designed to explore systematically these various sources of opinions regarding the regulation of pornography. Noting the variables emphasized in past research, we begin our analysis with genetic (sex, age), demographic (education, religion, marital and parental status), and political (party, ideology) variables. We then add to the predictive equation a number of intrapersonal social, psychological, and communication variables, such as normative attitudes about sex and relationships between men and women, exposure to pornography, and personal reactions to it. Finally, we add measures of pornography's perceived effects (both positive and negative) on others. This procedure allows us to assess the various relationships between attitudes toward the regulation of pornography and the above variables in a hierarchical model, where the unique influence of each variable on personal opinions can be discerned. 
We conducted a telephone survey as a class project for a course in mass communication and political behavior at the University of WisconsinMadison in the spring of 1986. Respondents were randomly sampled from the telephone directory for Dane County, Wisconsin, in which Madison is the largest city. The state capital and home of the state university, Madison has been known as a center of liberal and progressive political movements throughout this century. In view of the sensitive nature of the questions, male students interviewed male respondents, and female students interviewed female respondents.

The sample of 105 adult respondents included 64 ( 63 percent) women and 39 ( 37 percent) men. The mean age was 37 years, with an average of 13 to 15 years of education (i.e., some college). About three-fourths (74 percent) of

Table 1: Mean differences by sex and facfor loadings for scaled liems on sexual attltudes

\begin{tabular}{|c|c|c|c|c|c|c|c|}
\hline & \multicolumn{2}{|c|}{ Male } & \multicolumn{2}{|c|}{ Female } & \multirow[b]{2}{*}{$t$} & \multirow[b]{2}{*}{ df } & \multirow{2}{*}{$\begin{array}{l}\text { Factor } \\
\text { loads }\end{array}$} \\
\hline & $n$ & $\mathrm{x}$ & $n$ & $\bar{x}$ & & & \\
\hline \multicolumn{8}{|l|}{ Sexual mores } \\
\hline People shouldn't have oral sex & 40 & 3.35 & 70 & 3.61 & -.99 & 61 & 1.0 \\
\hline $\begin{array}{l}\text { It's } O . K \text {. for a man to have sex } \\
\text { before marrioge }\end{array}$ & 40 & 1.95 & 74 & 2.18 & -1.06 & 80 & -.78 \\
\hline $\begin{array}{l}\text { A woman should be a virgin } \\
\text { when she marries }\end{array}$ & 39 & 3.08 & 74 & 3.43 & -1.20 & 67 & .78 \\
\hline $\begin{array}{l}\text { It's O.K. to have sex outside } \\
\text { marriage }\end{array}$ & 39 & 2.64 & 74 & 2.99 & -1.24 & 71 & .52 \\
\hline $\begin{array}{l}\text { The way some women dress is } \\
\text { asking for trouble }\end{array}$ & 41 & 3.37 & 75 & 3.57 & -.71 & 78 & .65 \\
\hline $\begin{array}{l}\text { It's O.K. if a wife contradicts her } \\
\text { husband in public } \\
\text { Eigenvalue }=3.3\end{array}$ & 40 & 1.93 & 73 & 2.25 & -1.47 & 87 & -.70 \\
\hline \multicolumn{8}{|l|}{ Attitudes toward men } \\
\hline $\begin{array}{l}\text { A man has to show who's boss } \\
\text { right from the start }\end{array}$ & 41 & 3.54 & 75 & 4.24 & $-2.46^{\circ}$ & 62 & .62 \\
\hline $\begin{array}{l}\text { A man is sometimes justified in } \\
\text { hitting his wife or girlfriend }\end{array}$ & 40 & 4.08 & 76 & 4.62 & $-2.02^{*}$ & 63 & .83 \\
\hline $\begin{array}{l}\text { Women are sly and manipu- } \\
\text { lating in their relationships with } \\
\text { men } \\
\text { Eigenvalue }=1.37\end{array}$ & 41 & 3.10 & 74 & 3.77 & $-2.41^{*}$ & 69 & .66 \\
\hline \multicolumn{8}{|l|}{ Attitudes toward women and rape } \\
\hline $\begin{array}{l}\text { A healthy woman can escape } \\
\text { a rapist if she wants to }\end{array}$ & 39 & 4.05 & 74 & 4.20 & -.63 & 63 & .70 \\
\hline $\begin{array}{l}\text { A girl who lets petting get out } \\
\text { of hand deserves what she gets }\end{array}$ & 39 & 3.39 & 72 & 3.67 & -.97 & 70 & .61 \\
\hline $\begin{array}{l}\text { Many women have an uncon- } \\
\text { scious desire to be raped } \\
\text { Eigenvalue }=1.64\end{array}$ & 39 & 3.51 & 71 & 4.31 & $-2.49^{\star}$ & 55 & .80 \\
\hline
\end{tabular}

$* p<.05 \quad * p<.01$. 
those surveyed identified themselves with a religion (primarily Catholic and Lutheran), and 26 percent named no religion. Sixty-one percent of respondents were married, 28 percent were single, and 11 percent were divorced or widowed; 37 percent had no children.

Nearly half ( 48 percent) of those interviewed considered themselves liberal, 29 percent conservative, and 23 percent neither. Forty percent identified themselves as Democrats, 20 percent as Republicans, and the remaining 40 percent as neither. The unusually liberal-Democratic preponderance of our setting makes it an appropriate one for examining the new concerns violent pornography is creating in liberal circles.

The literature suggests that exposure to pornography can be related to attitudes toward sex, and to sexual callousness, as well as to attitudes toward rape, support for women's causes, and compassion for women in general (see, e.g., $14,15,19)$. Our survey thus included several questions designed to tap these attitudes. Sexual mores were measured by questions about whether men and women should have premarital sex and whether they should engage in oral sex. Questions about sex-role stereotyping and relationships between men and women (e.g., 2) were also included. Each item was measured on a five-point scale, with $1=$ "strongly agree" and $5=$ "strongly disagree."

A factor analysis revealed three underlying dimensions that were used to create indices of "sexual mores," "sex-role attitudes toward men," and "sex-role attitudes toward women and rape" (see Table 1). The results indicated that our respondents tended to have fairly liberal views on sexual mores and on attitudes toward sex roles and relationships. However, as shown in Table 1, women tended to disagree more strongly than men with statements about attitudes toward women and men. Specifically, women were significantly more likely to strongly disagree that a man is sometimes justified in hitting his wife or girlfriend, that women are sly and manipulating in their relationships with men, that a man has to show a woman who's boss right from the start, and that many women have an unconscious desire to be raped.

Use of pornography among our sample was not widespread. We asked several questions about exposure to pornography, including movies, television soap operas, and magazines. Responses to these questions were later combined in additive scales.

We asked respondents if they ever watched unedited $\mathrm{R}$ - or X-rated movies on pay TV, on VCRs, or in theaters. Men were three times more likely than women to watch X-rated or sexually explicit movies on pay television or a videocassette recorder, but less than half of the men in the survey had done so recently.

About 86 percent of those interviewed had seen an R-rated movie in a theater, but only about half had seen an X-rated movie in a theater.

Even though their content is less sexually explicit, our survey also included questions about exposure to daytime or evening soap operas. Overall, about one-half of the respondents had watched "Hill Street Blues" (50 percent) and about one-third had watched "Dallas" (37 percent), "Dynasty" ( 28 percent), or 
daytime soap operas ( 34 percent), although women tended to watch these soaps more frequently. Respondents who had seen these television programs were asked how much of the content they found to be sexually oriented. On a 4-point scale, where 1 means "none" and 4 means "a lot," "Dynasty" and daytime soaps were considered more sexually oriented than "Dallas" ( $\overline{\mathrm{x}} \mathrm{s}=3.24$, 3.22 , and 3.06, respectively) or "Hill Street Blues" ( $\overline{\mathrm{x}}=1.15)$. However, women regarded these soaps as more sexually oriented than men $\mathrm{did}(\mathrm{t}=$ $-2.38, \mathrm{df}=25,64, \mathrm{p}<.05)$.

We read the names of the nine most popular sexually explicit magazines to respondents and asked if they had ever seen them and, if so, how often they had looked at each within the last year. Only Playboy, Playgirl, and Penthouse had been seen by a majority of those surveyed, and Playboy was the one read most often, by as many as one person in ten, and one out of every five men. Overall, men had viewed more of these sexually oriented magazines than women had $(t=4.11$, df $=40,69, \mathrm{p}<.01)$.

We asked respondents who reported exposure to violent and nonviolent pornography to recall two movies or videos they had seen, one that was sexually oriented but not violent and another in which sex and violence were associated. Taking one movie at a time, we read respondents a list of adjectives and asked how much each applied to their reactions to each movie on a 5-point scale, where 1 meant "not at all" and 5 meant "a lot." These reactions to pornography were later categorized as positive (aroused, captivated), negative (shocked, angry, embarrassed, frightened, offended), or cognitive (curious, interested, enlightened, amused), and combined in additive scales.

Men and women reported similar reactions to sexually oriented movies and videos they had seen, although women said they felt more "angry" ( $\mathrm{t}=-3.46$, $\mathrm{df}=36,60, \mathrm{p}<.01)$ and men were more "amused" $(\mathrm{t}=2.99 ; \mathrm{df}=36,60, \mathrm{p}$ $<.01)$. Stronger reactions were reported by those who had seen films that mixed violence with sex; both men and women, although especially women, said they felt "shocked," "angry," and "offended" by violence-sex portrayals. Reactions to sexually oriented magazines and books were more positive among men, who more often said they felt "amused," "aroused," or "interested." Women were more likely to report feeling "shocked" and "offended" by these materials. A look at the overall responses to pornography shows that men tended to have more positive $(\mathrm{t}=2.94, \mathrm{df}=40,69, \mathrm{p}<.01)$ and cognitive $(\mathrm{t}$ $=3.26, \mathrm{df}=40,69, \mathrm{p}<.01)$ reactions to both the films and magazines they had seen, and less negative reactions $(t=-3.10, \mathrm{df}=40,69, \mathrm{p}<.01)$ than women did.

\section{Respondents generally agreed that pornography affects people's sexual} attitudes and behavior. Our survey included questions about whether pornography has positive and negative effects on individual users and on relationships between men and women. As seen in Table 2, men were significantly more likely than women to agree that pornography is a form of sex education, that it releases sexual tension for someone who is otherwise unfulfilled, and that it can improve viewers' sex lives. Both sexes also perceived negative 


\begin{tabular}{|c|c|c|c|c|c|c|c|}
\hline & \multicolumn{2}{|c|}{ Male } & \multicolumn{2}{|c|}{ Female } & \multirow[b]{2}{*}{$\dagger$} & \multirow[b]{2}{*}{$d f$} & \multirow{2}{*}{$\begin{array}{l}\text { Factor } \\
\text { loads }\end{array}$} \\
\hline & $n$ & 8 & $n$ & $\bar{R}$ & & & \\
\hline \multicolumn{8}{|l|}{ Interpersonal effects } \\
\hline $\begin{array}{l}\text { Pornography dehumanizes wom- } \\
\text { en }\end{array}$ & 38 & 2.34 & 74 & 2.00 & 1.46 & 64 & .80 \\
\hline $\begin{array}{l}\text { Pornography makes men treat } \\
\text { women with less respect }\end{array}$ & 36 & 2.61 & 74 & 2.34 & 1.01 & 57 & .91 \\
\hline $\begin{array}{l}\text { Pornography makes women } \\
\text { treat men with less respect }\end{array}$ & 34 & 2.68 & 72 & 2.64 & .13 & 53 & .86 \\
\hline $\begin{array}{l}\text { Many people imitate what they } \\
\text { see in pornography }\end{array}$ & 35 & 2.54 & 69 & 2.17 & 1.49 & 58 & .80 \\
\hline $\begin{array}{l}\text { Pornography users are less likely } \\
\text { to be sexually fulfilled with their } \\
\text { partners } \\
\text { Eigenvalue }=1.72\end{array}$ & 35 & 2.66 & 67 & 2.79 & -.46 & 56 & .69 \\
\hline \multicolumn{8}{|l|}{ Positive effects } \\
\hline $\begin{array}{l}\text { Pornography is a form of sex ed- } \\
\text { ucation } \\
\text { Pornography can improve a }\end{array}$ & 40 & 3.15 & 76 & 3.96 & $-2.97^{\circ \bullet}$ & 65 & .87 \\
\hline viewer's sex life & 39 & 2.46 & 68 & 3.13 & $-2.68^{* *}$ & 75 & .91 \\
\hline $\begin{array}{l}\text { Pornography can release ten- } \\
\text { sion for someone who is unful- } \\
\text { filled } \\
\text { Eigenvalue }=4.19\end{array}$ & 32 & 2.22 & 67 & 2.88 & $-2.41^{*}$ & 53 & .82 \\
\hline
\end{tabular}

* $\overline{p<.05 * p<.01}$

effects, including the beliefs that pornography dehumanizes women and that it causes men and women to lose respect for one another.

We did not include questions specifically related to proposals that redefine pornography as a violation of women's civil rights because we assumed that many respondents might not have heard of such proposals. However, we did ask about and find general popular support for one of the assertions used as a basis for this alternative approach: Respondents of both sexes agreed equally strongly that violent pornography violates women's civil rights. ${ }^{1}$

To measure attitudes toward regulation of pornography we asked seven ques tions, combining responses in an additive scale where a higher score indicated greater support for regulation. These items were related to the role of government in this policy area, including the importance of the issue to the government and to the local community, and whether the government should legislate morality; alternative types of pornography regulation, such as a community screening panel; individual access to pornography (whether anyone who

\footnotetext{
${ }^{1}$ Proponents of this approach contend that allowing injured parties rather than the state to fle civil suits against creators and distributors of pornography does not constitute censorship, unlike the obscenity approach. However, many traditional liberals (including the American Civil Liberties Union) argue that both the civil rights and obscenity approaches result in censorship.
} 
wanted pornographic materials should be allowed to have them); and producers (should selling pornography be prohibited and should it be a punishable crime).

Despite our respondents' primarily negative views of pornography's effects, nearly two-thirds ( 65 percent) said that pornographic materials should be protected by freedoms of speech and of the press. In addition, a majority opposed government-generated efforts to control pornography. However, women were somewhat (although not significantly) more supportive than men of antipornography legislation. Women also agreed more strongly that pornography is an important community issue $(\mathrm{t}=2.55, \mathrm{df}=39,72, \mathrm{p}<.05)$.

The combined "censorship" scale was used as the dependent variable in a hierarchical regression procedure. In general, as shown in Table 3, the strongest proponents of regulating pornography tended to be older women, who were less educated, more religious, and had fewer children. Conservatives tended to favor regulation more than liberals, particularly among women, but this relationship was not statistically significant. In addition, zespondents with more conservative sexual mores (particularly men) and with more conservative sex-role attitudes also tended to favor stricter controls on pornography.

As Table 3 shows, exposure to pornography was a significant predictor of attitudes toward regulation, particularly among those who had viewed sexually explicit movies and magazines and those who perceived television soap operas to be less sexually oriented $\left(\mathrm{R}^{2}=.11\right)$. This relationship was stronger among women $\left(R^{2}=.15\right)$ than men $\left(R^{2}=.05\right)$. However, by far the strongest predictor of attitudes toward regulation of pornography among all respondents was perceived effects, accounting for 47 percent of the variance. Specifically, and unexpectedly, those who perceived pornography to have the greatest effects were opposed to its being regulated. These perceived effects were primarily negative, including deleterious effects on interpersonal relations between the sexes and violation of women's civil rights. This finding was stronger for men $\left(R^{2}=\right.$ .66) than women $\left(\mathrm{R}^{2}=.35\right)$.

\section{Our results support the arguments posited by those critical of so-called "obscenity" laws regarding the difficulty of defining community stan-} dards. Regular use of pornography among our sample was not widespread, but many had seen sexually explicit violent and nonviolent movies and television programs. Although women generally reacted more negatively than men, responses varied widely. Clearly, no "community" standard was evident.

A statewide or nationwide survey might reveal different results than we found in this predominantly liberal community. The regression results, however, suggest that political leaning (at least along a traditional liberal-conservative continuum) was not a significant predictor of attitudes toward regulation of pornography. On the liberal side of the political spectrum, opinions on pornography appear to be rooted not in general political attitudes but in specific beliefs about pornography and its effects.

Our results also support previous research suggesting that older women are the strongest advocates of traditional measures aimed at regulating pornogra- 


\begin{tabular}{|c|c|c|c|c|c|}
\hline & $\begin{array}{l}\text { Corre- } \\
\text { lation }\end{array}$ & Beta & $\begin{array}{l}\text { Cumula- } \\
\text { tive } R^{2}\end{array}$ & $\begin{array}{l}\mathrm{R}^{2} \\
\text { change }\end{array}$ & $\begin{array}{l}F\left(R^{2}\right. \\
\text { change) }\end{array}$ \\
\hline \multicolumn{6}{|l|}{ Genetic } \\
\hline $\begin{array}{l}\text { Sex } \\
\text { Age }\end{array}$ & $\begin{array}{l}-.11 \\
-.18\end{array}$ & $\begin{array}{l}-.11 \\
-.18\end{array}$ & .05 & .05 & 2.67 \\
\hline \multicolumn{6}{|l|}{ Demographic } \\
\hline $\begin{array}{l}\text { Education } \\
\text { Religion } \\
\text { Marital status } \\
\text { Children }\end{array}$ & $\begin{array}{r}.22 \\
-.20 \\
.01 \\
.19\end{array}$ & $\begin{array}{r}.21 \\
-.15 \\
-.07 \\
.15\end{array}$ & .12 & .08 & 2.41 \\
\hline \multicolumn{6}{|l|}{ Political views } \\
\hline $\begin{array}{l}\text { Leaning } \\
\text { Democrat } \\
\text { Republican }\end{array}$ & $\begin{array}{l}-.23 \\
-.04 \\
-.06\end{array}$ & $\begin{array}{r}-.16 \\
-.01 \\
.00\end{array}$ & .14 & .02 & .85 \\
\hline \multicolumn{6}{|l|}{ Sexual attitudes } \\
\hline $\begin{array}{l}\text { Sexual mores } \\
\text { Attitudes toward men } \\
\text { Attitudes toward women }\end{array}$ & $\begin{array}{l}.30 \\
.07 \\
.12\end{array}$ & $\begin{array}{r}.20 \\
-.01 \\
.08\end{array}$ & .17 & .03 & 1.29 \\
\hline \multicolumn{6}{|l|}{ Exposure to pornography } \\
\hline $\begin{array}{l}\text { Movie exposure } \\
\text { TV exposure } \\
\text { TV sex } \\
\text { Magazine exposure }\end{array}$ & $\begin{array}{r}.26 \\
-.03 \\
-.28 \\
.19\end{array}$ & $\begin{array}{r}.22 \\
.03 \\
-.27 \\
.09\end{array}$ & .28 & .11 & $3.76^{\circ}$ \\
\hline \multicolumn{6}{|l|}{ Reactions to pornography } \\
\hline $\begin{array}{l}\text { Negative reaction } \\
\text { Positive reaction } \\
\text { Cognitive reaction }\end{array}$ & $\begin{array}{r}-.31 \\
.19 \\
.12\end{array}$ & $\begin{array}{r}-.10 \\
.12 \\
-.10\end{array}$ & .30 & .02 & 1.01 \\
\hline \multicolumn{6}{|l|}{ Perceived effects } \\
\hline $\begin{array}{l}\text { Civil rights } \\
\text { Interpersonal effects } \\
\text { Positive effects }\end{array}$ & $\begin{array}{l}.48 \\
.77 \\
.33\end{array}$ & $\begin{array}{l}.48 \\
.62 \\
.21\end{array}$ & .77 & .47 & $65.22^{* *}$ \\
\hline
\end{tabular}

A higher score on the dependent variable represents greater opposition to pornography regulation. The following are coded as dummy variables: sex $(1=$ male, 2 = female): religion ( $1=$ any religious affiliation, $0=$ no religious affiliation); marital status ( $1=$ married, $0=$ not married); children ( 1 = has children, $0=$ has no children); political leaning ( $1=$ conservative, 0 = liberal): Democrat ( 1 = Democrat, 0 = not a Democrat); Republican ( 1 $=$ Republican, $0=$ not a Republican).

$\cdot p<.01 \quad \cdots p<.001$.

phy. These women tend to see less pornography than other groups and to react more negatively to what they do see.

Although nearly two-thirds of our sample were women, sex and other demographic variables, as well as exposure factors, accounted for only a small portion of the variance. By far the largest predictor of attitudes toward regulation was the perceived effects of pornography on others. Regardless of their own experiences with pornography, respondents of both sexes tended to agree that pornography affects other people's sexual attitudes and behavior in both negative and positive ways. As such, our results lend support for the "third-person 
effect" hypothesis, which predicts that people believe exposure to mass communication has a greater effect on others than on themselves (6).

Men tended to agree more strongly with the potentially positive effects of pornography on others: that it releases sexual tension for someone who is otherwise unfulfilled, and that it lowers inhibitions toward sex. However, most men and women agreed that pornography may have negative effects: that it dehumanizes women, that it causes each sex to lose respect for the other, and that violent pornography violates women's civil rights. Future research is needed to determine the direction of causality between perceived effects and opinions about regulation of pornography.

The findings in this study indicate a base of popular support in Dane County for assertions by feminist groups, now echoed by conservatives as well, about the potentially harmful social effects of pornography not only on women but also on interpersonal relations between men and women. The findings suggest, however, that although both men and women are quite concerned about the effects of pornography, many feel that traditional solutions, such as community screening panels or criminal sanctions that affect First Amendment rights, are not the answer. Nearly two-thirds of our sample (65 percent) said that pornographic materials should be protected by freedom of speech and the press. Thus, finally, our findings reveal a classic dilemma for the liberal community: Are the potential solutions worse than the perceived problems?

\section{References}

1. Brannigan, A. "Pornography and Behavior: Alternative Explanations. A Critique." Journal of Communication 37(3), Summer 1987, pp. 185-189.

2. Burt, M. R. "Cultural Myths and Support for Rape." Journal of Personality and Social Psychology $38(2), 1980$, pp. $217-230$.

3. Byrne, D. and J. Lambeth. "The Effect of Erotic Stimuli on Sexual Arousal, Evaluative Responses and Subsequent Behavior." Tecbnical Report of the Commission on Obscenity and Pornography, Volume 8. Washington, D.C.: U.S. Government Printing Office, 1970, pp. 41-67.

4. Christensen, F. "Sexual Callousness Revisited. A Critique." Journal of Communication 36(1), Winter 1986, pp. 174-184.

5. Christensen, F. "Effects of Pornography: The Debate Continues. A Critique." Journal of Communication 37(1), Winter 1987, pp. 186-187.

6. Davison, W. P. "The Third-Person Effect in Communication." Public Opinion Quarterly 47(1), Spring 1983, pp. 1-15.

7. Donnerstein, E. and L. Berkowitz. "Victim Reactions in Aggressive Erotic Films as a Factor in Violence Against Women." Journal of Personality and Social Psychology 41(4), 1981, pp. 710-724.

8. Gross, L. "Pornography and Social Science Research: Serious Questions. A Critique." Journal of Communication 33(4), Autumn 1983, pp. 107-111.

9. Herrman, M. S. and D. C. Bordner. "Attitudes Toward Pornography in a Southern Community." Criminology 21, 1983, pp. 349-374. 
10. Howard, J., C. Reifler, and M. Liptzin. "Effects of Exposure to Pornography." Technical Report of the Commission on Obscenity and Pornography, Volume 8. Washington, D.C.: U.S. Government Printing Office, 1970 , pp. 97-132.

11. Lederer, L. (Ed.). Take Back the Night: Women on Pornograpby. New York: William Morrow, 1980.

12. Linz, D. and E. Donnerstein. "The Methods and Merits of Pornography Research. A Critique." Journal of Communication 38(2), Spring 1988, pp. 180-184.

13. Malamuth, N. M. and V. Billings. "The Functions and Effects of Pornography: Sexual Communication Versus the Feminist Models in Light of Research Findings." In J. Bryant and D. Zillmann (Eds.), Perspectives on Media Effects. Hillsdale, N.J.: Lawrence Erlbaum, 1986.

14. Malamuth, N. M. and J. V. P. Check. "The Effects of Mass Media Exposure on Acceptance of Violence Against Women: A Field Experiment." Journal of Researcb in Personality 15, 1981, pp. 436446.

15. Malamuth, N. M. and E. Donnerstein. Pornography and Sexual Aggression. Orlando, Fla.: Academic Press, 1984.

16. U.S. Attorney General's Commission on Pornography. Final Report. Washington, D.C.: U.S. Government Printing Office, 1986.

17. U.S. Commission on Obscenity and Pornography. Report. Washington, D.C.: U.S. Government Printing Office, 1970.

18. "The War Against Pornography." Newsweek, March 18, 1985, pp. 58-66.

19. Zillmann, D. and J. Bryant. "Pornography, Sexual Callousness, and the Trivialization of Rape." Jour. nal of Communication 32(4), Autumn 1982, pp. 10-21.

20. Zillmann, D. and J. Bryant. "Pornography and Social Science Research: Higher Moralities. A Response." Joumal of Communication 33(4), Autumn 1983, pp. 111-114.

21. Zillmann, D. and J. Bryant. "Sexual Callousness Revisited. A Response." Joumal of Communication 36(1), Winter 1986, pp. 184-188.

22. Zillmann, D. and J. Bryant. "Pornography and Behavior: Alternative Explanations. A Reply." Journal of Communication 37(3), Summer 1987, pp. 189-192.

23. Zillmann, D. and J. Bryant. "The Methods and Merits of Pornography Research. A Response." Journal of Communication 38(2), Spring 1988, pp. 185-192.

24. Zillmann, D. and B. S. Sapolsky. "What Mediates the Effect of Mild Erotica on Annoyance and Hostile Behavior in Males?' Joumal of Personality and Social Psychology 35(8), 1977, pp. 587-596. 